\title{
HUBUNGAN POLA KONSUMSI ALA VEGETARIAN TERHADAP LEMAK VISCERAL
}

\author{
Relationship of Vegetarian Dietary Patterns and Visceral Fat \\ Dini Lestrina, Ginta Siahaan, Efendi Nainggolan \\ Jurusan Gizi Poltekkes Kemenkes RI, Medan \\ E-mail: ginzsiahaan@gmail.com
}

\begin{abstract}
Vegetarian, vegan and non-vegan, can lower the risk of metabolic syndrome disease caused by central obesity by measuring waist circumference and the general obesity by assessing Body Mass Index (BMI). One of alternative to prevent can be done by changing the pattern of diet habits from omnivores (the consumption of animal products and vegetable and dairy) become vegetarian (vegetable and dairy product consumption). The purpose of this study was to analyze differences in waist circumference and BMI in terms of nutrient intake in the vegetarian community members Indonesia Vegetarian Society (IVS) at the age of 30-58 years in Maha Vihara Maitreya Medan. This study was an observational with cross sectional design. These research subjects are divided into two groups, 42 vegans and 42 non-vegans selected by screening, and then determined by purposive sampling. Nutrient intake data collected by interview using the 24-hour recall, while the antropometry measurement using a measuring tape, scales and microtoise. Analysis were done using Independent T-test. The results showed there's difference of waist circumference between vegan and non vegan $(p=0.008)$, but there is no difference of IMT $(p=0105)$. Statistically, energy and protein intake was not different ( $p>0.05)$, however, there were differences found in carbohydrate intake $(p=0.001)$ and total fat $(p=0.005)$ in the vegan and non vegan. The continue research on the diet of vegan vegetarian adverse event to metabolic syndrome and the characteristics of the food based on local cultural wisdom needs to be done.
\end{abstract}

Keywords: waist circumference, BMI, nutrition intake, vegetarian

\begin{abstract}
ABSTRAK
Vegetarian dapat menurunkan risiko penyakit sindroma metabolik yang diakibatkan oleh obesitas sentral dengan mengukur lingkar pinggang serta obesitas umum dengan menilai Indeks Massa Tubuh (IMT). Salah satu alternatif pencegahannya dapat dilakukan dengan mengubah kebiasaan makan dari omnivora menjadi vegetarian. Tujuan penelitian ini adalah menganalisis perbedaan lingkar pinggang dan Indeks Massa Tubuh (IMT) ditinjau dari asupan zat gizi pada komunitas vegetarian anggota Indonesia Vegetarian Society (IVS) pada usia 30-58 tahun di Maha Vihara Maitreya Medan. Penelitian ini bersifat observasional dengan rancangan cross-sectional. Subyek penelitian ini dibedakan menjadi dua kelompok: 42 vegan dan 42 nonvegan dipilih dengan melakukan screening. Kemudian ditentukan secara purposive sampling. Pengumpulan data asupan zat gizi dilakukan dengan wawancara menggunakan food recall 24 jam, sedangkan pengukuran ukuran tubuh (antropometri) menggunakan pita ukur, timbangan dan microtoise. Selanjutnya dilakukan analisis data menggunakan uji $T$-Independent. Hasil penelitian menunjukkan, lingkar pinggang pada vegan berbeda dengan nonvegan $(p=0,008)$, tetapi IMT tidak berbeda $(p=0,105)$. Asupan jumlah energi dan jumlah protein secara statistik tidak berbeda $(p>0,05)$, tetapi ditemukan perbedaan asupan karbohidrat $(p=0,001)$ dan jumlah lemak $(p=0,005)$ pada vegan dan non-vegan. Perlu dilakukan penelitian lanjutan tentang pola makan vegetarian vegan terhadap kejadian sindroma metabolik serta karakteristik kearifan pangan berdasarkan budaya setempat.
\end{abstract}

Kata kunci: lingkar pinggang, IMT, asupan zat gizi, vegetarian 


\section{PENDAHULUAN}

$\mathrm{P}$ roses degenerasi merupakan proses fisiologis yang akan dialami oleh manusia seiring pertambahan umurnya. Degenerasi adalah istilah medis yang digunakan untuk menjelaskan suatu keadaan tubuh yang mengalami penurunan fungsi tubuh. Tubuh mengalami perubahan fungsi dari keadaan normal menjadi lebih buruk yang dimulai pada usia 30 tahun. Penyakit yang mengiringi proses ini memang berhubungan erat dengan bertambahnya umur seseorang. Namun, penyebab utama yang mempercepat timbulnya penyakit kronis adalah perubahan gaya hidup, temasuk pola makan gaya modern siap saji, yang umumnya mengandung lemak, protein dan garam tinggi, tetapi rendah serat. ${ }^{1}$

Penyakit Jantung Koroner (PJK) merupakan salah satu penyakit kronis yang masih menjadi masalah kesehatan di dunia. Angka kematian akibat PJK menduduki urutan pertama penyebab kematian di dunia. WHO tahun 2013 mencatat lebih dari 7,3 juta orang meninggal akibat PJK di seluruh dunia. Angka ini diperkirakan akan meningkat, 1,5 juta kasus baru penderita PJK dan 478 ribu orang meninggal akibat penyakit yang sama. ${ }^{2}$

Survei Kesehatan Rumah Tangga (SKRT) tahun 2001 memperlihatkan bahwa penyakit kardiovaskular menyebabkan kematian sebesar 26,3 persen. Riskesdas 2013 menunjukkan, prevalensi penyakit pembuluh darah seperti hipertensi dan penyakit jantung di Indonesia berdasarkan pengukuran tekanan darah yang sangat tinggi, yaitu sebesar 31,7 persen pada tahun 2007 dan 25,8 persen pada tahun 2013, sedangkan Riskesdas 2013 menunjukkan hipertensi sebesar 9,5 persen dan stroke 12,1 per 1000 penduduk. $^{3}$

Selain PJK, pola makan dan gaya hidup yang tidak sehat dapat menyebabkan sindroma metabolik. Sindroma metabolik merupakan kumpulan kelainan metabolik yang berkaitan dengan peningkatan risiko kardiovaskular yang meliputi resistensi insulin, obesitas sentral, dislipidemia, dan hipertensi. Sindroma metabolik juga merupakan faktor risiko multipel yang berpengaruh terhadap kejadian aterosklerosis yang menjadi penyebab PJK. ${ }^{4}$

Beberapa kondisi yang terkait langsung dengan sindroma metabolik salah satunya adalah obesitas. Obesitas adalah keadaan adanya kelebihan lemak dalam tubuh. Penimbunan lemak dapat terjadi di daerah pinggang (obesitas sentral) dan di seluruh tubuh (obesitas umum). Kriteria obesitas dapat ditentukan berdasarkan Indeks Massa Tubuh (IMT) yang melebihi batas normal karena penyebab obesitas adalah kelebihan lemak. Orang dengan IMT berlebih memiliki risiko yang lebih tinggi terhadap penyakit Diabetes Mellitus (DM), di mana resistensi insulin merupakan salah satu dari penyakit sindroma metabolik. ${ }^{5,6}$ Data Riskesdas 2010 menunjukkan, persentase penduduk dewasa (>18 tahun) di Sumatera Utara yang memiliki berat badan lebih (overweight) sebesar 11,9 persen, sedangkan persentase kumulatif di seluruh Indonesia sebesar 10,0 persen. Untuk kegemukan (obesitas), persentase penduduk dewasa di Sumatera Utara sebesar 13,5 persen, sedangkan persentase kumulatif seluruh Indonesia sebesar 11,7 persen. ${ }^{7}$

Obesitas sentral terkait langsung dengan PJK dibandingkan dengan obesitas umum. Obesitas sentral dapat diketahui dengan mengukur lingkar pinggang. Lingkar pinggang dapat digunakan untuk proksi banyaknya jaringan adiposa bagian dalam dan berhubungan langsung dengan massa lemak bebas. Jaringan adiposa atau lemak adalah istilah anatomi untuk longgarnya jaringan ikat penyusun adiposit. Berperan sebagai penyimpanan energi di jaringan lemak, dan juga sebagai bantalan pada tubuh. ${ }^{4}$ Menurut World Health Organization (WHO), batas lingkar pinggang untuk obesitas sentral bagi negara Asia, termasuk Indonesia, adalah $90 \mathrm{~cm}$ pada pria dan $80 \mathrm{~cm}$ pada wanita. Pengukurannya dilakukan antara permukaan otot rectus abdominalis dan dinding posterior abdomen selama respirasi. Ketebalan lemaknya disebut juga dengan obesitas visceral. ${ }^{8}$ Lingkar pinggang terbukti memiliki ketepatan yang cukup tinggi dibandingkan dengan lingkar panggul dan IMT. ${ }^{4}$ IMT adalah nilai yang diambil dari perhitungan antara berat badan $(\mathrm{kg})$ dibagi dengan dan tinggi badan kuadrat $\left(\mathrm{m}^{2}\right)$. Cara ini merupakan cara paling sederhana untuk menilai status obesitas orang dewasa. IMT dapat menjadi indikator atau menggambarkan kadar adipositas dalam tubuh seseorang, di mana batasan untuk IMT, yaitu gemuk, $>25.3,4$

Untuk dapat mempertahankan berat badan tetap dalam keadaan normal dan terhindar dari 
penyakit tidak menular (PJK dan DM) masyarakat mulai mengubah pola makan mereka menjadi pola makan yang lebih sehat. Salah satu caranya adalah dengan menjadi seorang vegetarian murni yang disebut dengan vegan dan nonvegan, yang terdiri dari vegetarian lakto, ovo, dan lakto-ovo., 2,9 Selain alasan ingin menjaga kesehatan, seseorang menjadi vegetarian juga dikarenakan alasan agama yang dianut, seperti komunitas Buddha, Kristen Advent, serta Hindu. Sementara bagi para wanita, menjadi vegetarian adalah untuk alasan kecantikan karena dapat menjaga kehalusan kulit. ${ }^{10}$ Selain itu, diet vegetarian dapat mengurangi penyakit akibat sindroma metabolik, seperti hipertensi, hiperglikemia, hiperlipidemia. ${ }^{9,11}$

Vegetarian merupakan suatu usaha manusia untuk hidup menyelaraskan diri dengan alam (back to nature). Vegan adalah vegetarian murni yang tidak mengonsumsi daging sama sekali, sedang nonvegan adalah vegetarian tidak murni, di mana masih mengonsumsi produk hewani (telur dan susu). Komunitas vegetarian adalah orang yang mengonsumsi sedikit produk hewani atau tidak sama sekali. Mereka mengonsumsi makanan yang tinggi karbohidrat, rendah lemak dan tinggi serat. ${ }^{12}$ Menurut data yang diperoleh dari Indonesia Vegetarian Society (IVS), jumlah komunitas vegetarian yang terdaftar di Indonesia pada tahun 1998 adalah sekitar 5000 anggota dan pada tahun 2007 mengalami peningkatan sekitar 60.000 orang. Sementara komunitas vegetarian di Sumatera Utara dan khususnya di Kota Medan pada tahun 2013 tercatat \pm 2.000 orang. Seiring dengan meningkatnya komunitas vegetarian, semakin banyak pula restoran-restoran khusus yang menyediakan menu vegetarian, berjumlah sekitar 56 restoran. Hal ini memungkinkan komunitas vegetarian menjadi lebih bergairah untuk menjalankan kedisiplinan pola konsumsi makanan ala vegetarian. Dengan banyak dibukanya restoran vegetarian, memungkinkan komunitas vegetarian dapat memilih jenis makanan yang lebih bervariasi. ${ }^{8}$

Berdasarkan kajian tersebut, penelitian ini bertujuan untuk mengetahui perbedaan lingkar pinggang dan IMT, ditinjau dari asupan energi, karbohidrat, protein dan lemak, pada komunitas vegetarian vegan dan nonvegan di Maha Vihara Maitreya Komplek Cemara Asri Medan.

\section{METODE PENELITIAN}

Penelitian ini bersifat observasional dengan rancangan penelitian cross-sectional (potong lintang). Populasi adalah seluruh komunitas vegetarian yang merupakan anggota IVS Medan yang bersembahyang di Maha Vihara Maitreya Komplek Cemara Asri Medan. Pemilihan sampel dilakukan dengan melakukan screening terlebih dahulu kemudian sampel ditentukan dengan purposive sampling. Kriteria sampel, anggota IVS Medan dan berumur $\geq 30$ 58 tahun. Berdasarkan kriteria sampel di atas diperoleh jumlah sampel 84 orang yang dibedakan menjadi vegan (42 orang) dan nonvegan (42 orang). Pembagian sampel menjadi 42 orang dikarenakan dari jumlah sampel yang ada, ditemukan 42 orang vegetarian murni (vegan), kemudian sebagai pembandingnya diambil 42 orang sampel yang berasal dari kelompok vegetarian nonvegan (lakto, ovo dan lakto-ovo).

Pengumpulan data dilakukan dengan wawancara dan pengukuran. Peneliti dibantu oleh 10 orang enumerator. Data yang diambil langsung dari sampel yang dikumpulkan melalui wawancara dengan mengisi form yng sudah disediakan dan observasi langsung ke lokasi penelitian. Data diolah dengan menggunakan pogram SPSS. Analisis data dilakukan univariat dan bivariate. Pengujian statistik dilakukan dengan menggunakan uji beda $T$ independent. Penelitian ini telah memperoleh persetujuan komisi etik penelitian bidang kesehatan dari Fakultas Kedokteran Universitas Sumatera Utara, No: 484/KOMET/FK USU/2014.

\section{Asupan Zat Gizi (Energi, Karbohidrat, Protein dan Lemak)}

Data asupan karbohidrat dan lemak diperoleh dengan dengan metode Food Recall 24 jam selama 3 hari tidak berturut. Hari yang direcall adalah Minggu, Rabu dan Jumat, hari ini dianggap sudah mewakili jumlah, variasi dan frekuensi makan masyarakat Indonesia yang berbeda.

\section{Pengukuran Lingkar Pinggang}

Pengukuran lingkar pinggang untuk mengetahui banyaknya jaringan adiposa bagian dalam dan berhubungan langsung dengan massa lemak bebas. Data lingkar pinggang diperoleh dengan cara mengukur lingkar 
pinggang menggunakan pita meteran dengan ketelitian $0,1 \mathrm{~cm}$.

\section{Pengukuran IMT}

Pengukuran IMT untuk mengetahui kadar adipositas pada tubuh seseorang. Data IMT diperoleh dengan cara mengukur berat badan menggunakan timbangan injak (Camry) yang memiliki ketelitian $0,1 \mathrm{~kg}$ dan mengukur tinggi badan menggunakan microtoise dengan ketelitian $0,1 \mathrm{~cm}$.

\section{Analisis Data}

Data yang diolah kemudian dianalisis dengan analisis univariat yang disajikan dalam distribusi frekuensi dan dianalisis berdasarkan persentase. Sementara analisis bivariat, melihat perbedaan lingkar pinggang dan IMT ditinjau dari asupan energi, karbohidrat, protein dan lemak pada komunitas vegetarian vegan dan vegetarian nonvegan, menggunakan uji beda TIndependent, yaitu dengan menggunakan bantuan komputer dengan program SPSS.

\section{HASIL}

\section{Karakteristik Sampel}

Karakteristik sampel pada penelitian ini meliputi jenis kelamin dan umur pada vegan dan nonvegan, yang berjumlah masing-masing 42 orang. Sebagian besar sampel berjenis kelamin perempuan $(59,5 \%)$, penyebaran umur bervariasi yang terbanyak pada kelompok usia 50-59 tahun (35,7\%). Karakteristik Komunitas Vegetarian dapat dilihat pada Tabel 1.

\section{Perbedaan Lingkar Pinggang dan IMT pada Komunitas Vegetarian Vegan dan Non- Vegan}

Lingkar pinggang adalah ukuran antropometri yang dapat digunakan untuk menentukan obesitas sentral. Lingkar pinggang dikatakan sebagai indeks yang berguna untuk menentukan obesitas sentral dan komplikasi metabolik yang terkait. ${ }^{3}$

Sementara Indeks Massa Tubuh (IMT) merupakan indikator yang dapat menilai status obesitas pada seseorang.5,9 IMT juga menggambarkan distribusi lemak tubuh yang sifatnya menyeluruh. Perbedaan lingkar pinggang dan IMT pada komunitas vegetarian vegan dan nonvegan dapat dilihat pada Tabel 2.

Tabel 2 menunjukkan analisis perbedaan lingkar pinggang pada komunitas vegetarian vegan dan nonvegan. Rata-rata lingkar pinggang vegan adalah $79,72 \mathrm{~cm}$, sedangkan pada nonvegan adalah $84,75 \mathrm{~cm}$. Dari hasil uji statistik dengan uji T Independent diperoleh nilai probabilitas (sig-tailed $=0,008$ ) $<0,05$, maka Ho ditolak dan $\mathrm{Ha}$ diterima, sehingga dapat disimpulkan bahwa pada alpha 5 persen, yaitu ada perbedaan rata-rata lingkar pinggang antara komunitas vegetarian vegan dan nonvegan.

Indeks Massa Tubuh (IMT) merupakan indikator yang dapat menilai status obesitas pada seseorang, tetapi tidak terlalu ideal untuk mengukur tingkat kegemukan seseorang. ${ }^{4}$ Tabel 3 menunjukkan analisis perbedaan Indeks Massa Tubuh (IMT) pada komunitas vegan dan nonvegan. Rata-rata IMT vegan adalah $22,73 \mathrm{~cm}$, sedangkan pada vegetarian nonvegan adalah $23,90 \mathrm{~cm}$. Dari hasil uji statistik dengan uji T Independent diperoleh nilai probabilitas (sig-tailed $=0,105)<0,05$, maka Ho diterima dan $\mathrm{Ha}$ ditolak, sehingga dapat disimpulkan bahwa pada alpha 5 persen, tidak ada perbedaan Indeks Massa Tubuh (IMT) antara komunitas vegan dan nonvegan. Sementara bila dilihat berdasarkan kategori, lingkar pinggang normal untuk laki-laki $\leq 90 \mathrm{~cm}$ dan perempuan $\leq 80 \mathrm{~cm}$. Distribusi kategori lingkar pinggang dapat dilihat pada Gambar 1.

Gambar 1 menunjukkan bahwa komunitas vegetarian vegan yang memiliki kategori lingkar pinggang normal untuk perempuan lebih besar $(47,6 \%)$, bila dibandingkan dengan lingkar pinggang normal untuk nonvegan $(23,8 \%)$, begitu juga dengan jenis kelamin laki-laki persentasenya lebih besar kelompok vegan $(33,3 \%)$ dibandingkan dengan laki-laki pada kelompok nonvegan (16,7\%). Sementara pada kategori lingkar pinggang lebih, baik perempuan maupun laki-laki didapati lebih besar pada kelompok nonvegan.

Kategori untuk IMT menurut WHO 2005 diklasifikasikan menjadi 3 yaitu: kurus $<18,5$ $\mathrm{kg} / \mathrm{m}^{2}$; normal $18,5-25 \mathrm{~kg} / \mathrm{m}^{2}$; dan gemuk $>25$ $\mathrm{kg} / \mathrm{m}^{2} .{ }^{14} \mathrm{Hal}$ ini dapat dilihat pada Gambar 2. 
Tabel 1

Karakteristik Sampel berdasarkan Jenis Kelamin dan Umur

\begin{tabular}{llcccc}
\hline & & \multicolumn{2}{c}{ Vegan } & \multicolumn{2}{c}{ Non-Vegan } \\
\cline { 3 - 6 } & & $\mathrm{n}$ & $\%$ & $\mathrm{n}$ & $\%$ \\
\hline \multirow{2}{*}{ Jenis Kelamin } & Laki-laki & 17 & 40,5 & 17 & 40,5 \\
& Perempuan & 25 & 59,5 & 25 & 59,5 \\
\multirow{3}{*}{ Umur } & 30-39 tahun & 14 & 33,3 & 14 & 33,3 \\
& 40-49 tahun & 13 & 31,0 & 13 & 31,0 \\
& 50-59 tahun & 15 & 35,7 & 15 & 35,7 \\
\hline
\end{tabular}

Tabel 2

Analisis Perbedaan Lingkar Pinggang dan IMT pada Komunitas Vegetarian Vegan dan Non-Vegan

\begin{tabular}{llccccc}
\hline \multirow{2}{*}{ Pengukuran } & $\begin{array}{c}\text { Jenis } \\
\text { Vegetarian }\end{array}$ & $\mathrm{n}$ & $\mathrm{X} \pm \mathrm{SD}$ & Min & Max & $\mathrm{p}$ \\
\hline Lingkar & Vegan & 42 & $79,72 \pm 7,97$ & 60,5 & 94 & 0,008 \\
Pinggang & Non Vegan & 42 & $84,75 \pm 9,03$ & 64,5 & 107,5 & \\
\multirow{2}{*}{ IMT } & & & & & & \\
& Vegan & 42 & $22,73 \pm 2,80$ & 16,86 & 28,78 & 0,105 \\
& Non Vegan & 42 & $23,90 \pm 3,67$ & 17,54 & 36,78 & \\
\hline
\end{tabular}

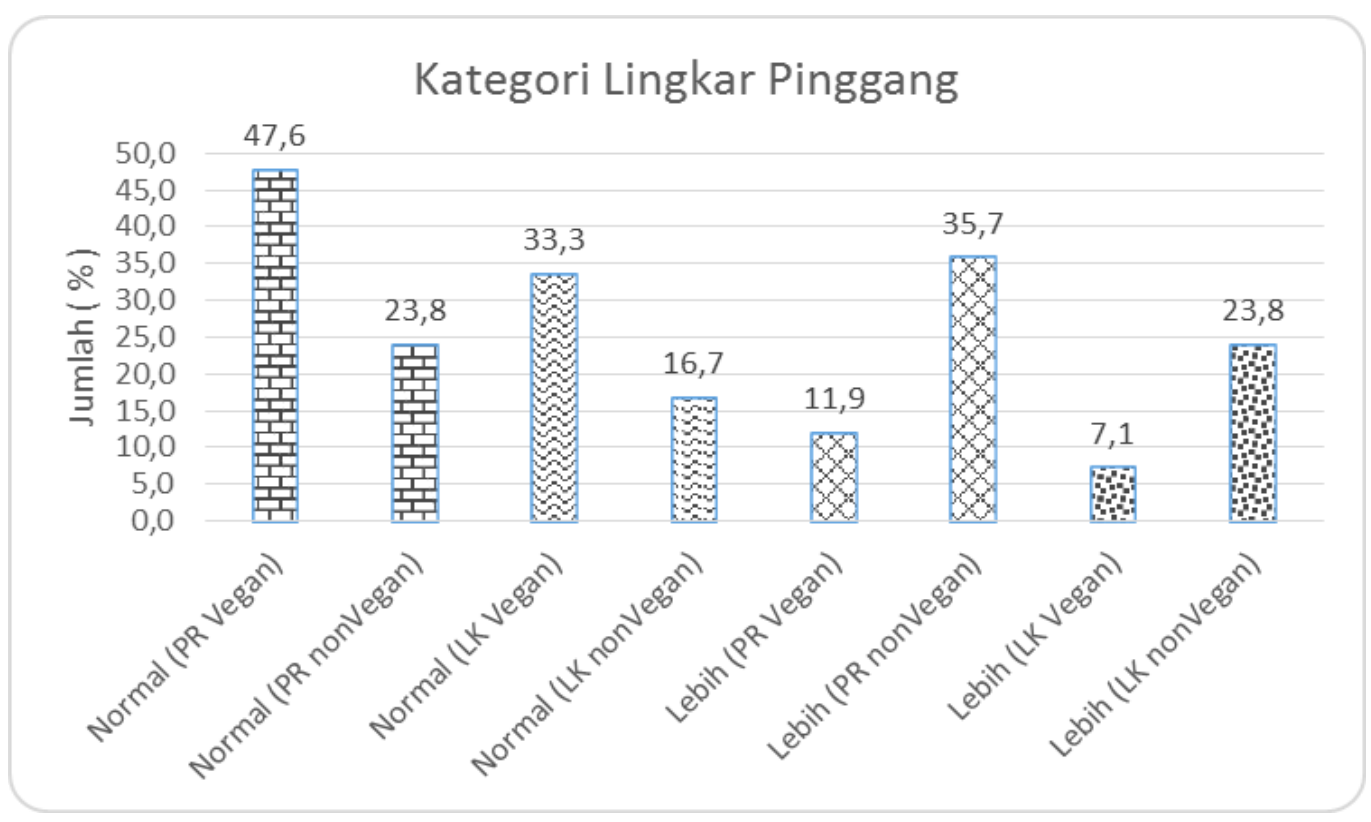

Gambar 1

Distribusi Lingkar Pinggang berdasarkan Jenis Kelamin 


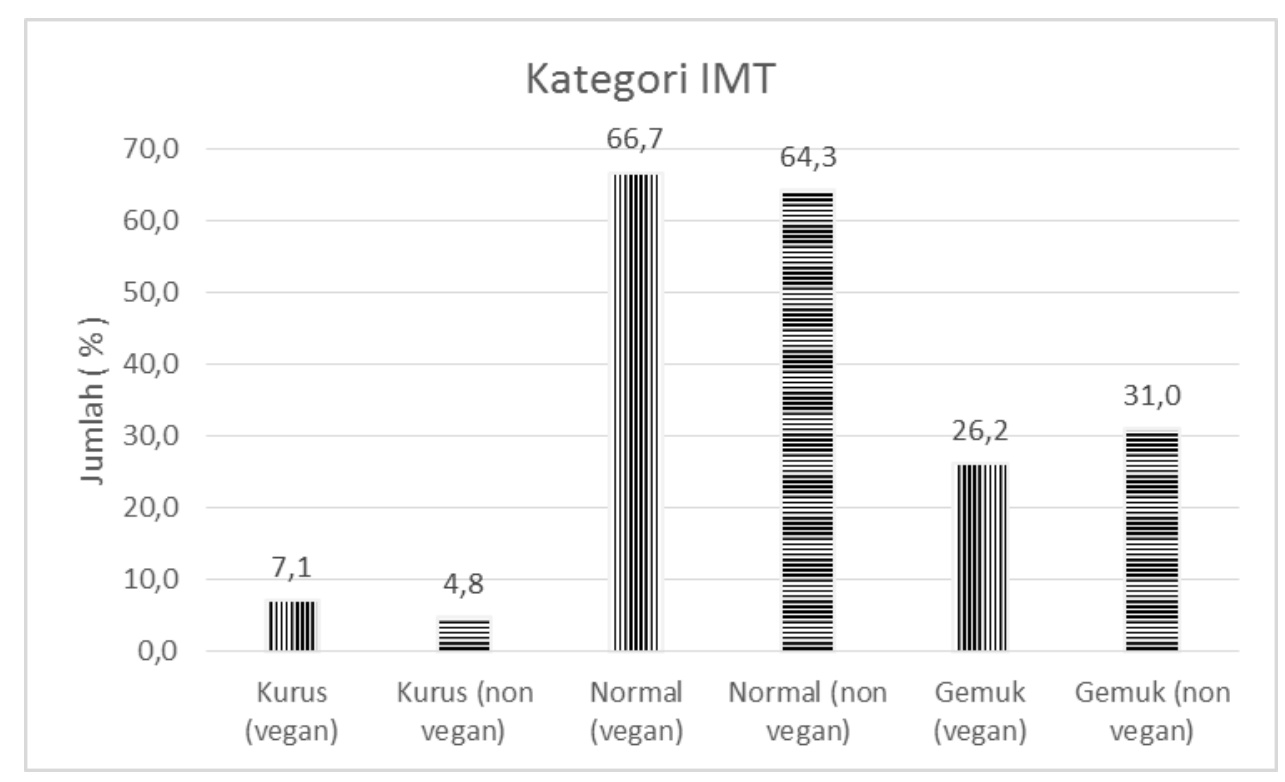

Gambar 2

Distribusi IMT pada Komunitas Vegan dan Non-Vegan

Tabel 3

Analisis Perbedaan Asupan Zat Gizi pada Komunitas Vegetarian Vegan dan Non-Vegan

\begin{tabular}{|c|c|c|c|c|c|c|}
\hline Asupan & $\begin{array}{l}\text { Kelompok } \\
\text { Komunitas }\end{array}$ & $\mathrm{n}$ & $X \pm S D$ & Min & Max & $p$ \\
\hline \multirow[t]{2}{*}{ Energi } & Vegan & 42 & $2091,81 \pm 124,09$ & 1808 & 2362 & 0,166 \\
\hline & Non-Vegan & 42 & $2126,5 \pm 102,61$ & 1938 & 2390 & \\
\hline \multirow[t]{2}{*}{ Karbohidrat } & Vegan & 42 & $340,84 \pm 38,27$ & 275,7 & 415,7 & 0,001 \\
\hline & Non-Vegan & 42 & $307,61 \pm 51,85$ & 221,3 & 416,1 & \\
\hline \multirow[t]{2}{*}{ Protein } & Vegan & 42 & $62,54 \pm 30,68$ & 42 & 94 & 0,578 \\
\hline & Non-Vegan & 42 & $59,73 \pm 11,05$ & 39 & 88 & \\
\hline \multirow[t]{2}{*}{ Lemak } & Vegan & 42 & $56,90 \pm 19,55$ & 27 & 112 & 0,005 \\
\hline & Non-Vegan & 42 & $66,78 \pm 21,51$ & 34 & 126 & \\
\hline
\end{tabular}

Gambar 2 di atas menunjukkan kategori IMT normal komunitas vegetarian vegan lebih besar $(66,7 \%)$ dibandingkan dengan komunitas vegetarian nonvegan. Sementara untuk IMT kategori gemuk, didapati persentasenya lebih kecil komunitas vegan $(26,2 \%)$ dibandingkan dengan komunitas nonvegan (31\%).

\section{Analisis Perbedaan Asupan Zat Gizi pada Komunitas Vegetarian Vegan dan Non- Vegan}

Asupan makanan yang berlebihan dan/atau penurunan pengeluaran energi menimbulkan energi positif. Keseimbangan energi positif yang terjadi dari asupan makanan yang berlebihan terutama berasal dari kelebihan asupan energi, lemak serta karbohidrat. $^{5}$ Perbedaan asupan zat gizi pada komunitas vegetarian vegan dan nonvegan dapat dilihat pada Tabel 3.

Energi memiliki peranan yang sangat besar bagi makhluk hidup. Energi digunakan manusia untuk menjalankan aktivitas. Namun, jika asupan energi yang tinggi disertai dengan pemakaian energi yang rendah dapat menyebabkan penimbunan lemak yang berakibat pada naiknya berat badan dan meningkatnya ukuran lingkar pinggang. ${ }^{8} 14$ Tabel 3 di atas menunjukkan, asupan energi vegetarian vegan sebesar 2091,81 Kkal/orang/hari, sedangkan asupan energi nonvegan $2126 \mathrm{Kkal} /$ orang/hari. Menurut hasil uji statistik diperoleh nilai $>0,05$, maka $\mathrm{Ho}$ diterima sehingga dapat disimpulkan tidak ada perbedaan asupan energi pada komunitas vegetarian vegan dan nonvegan. 
Karbohidrat adalah zat gizi berupa senyawa organik yang merupakan penyumbang energi terbesar. Karbohidrat merupakan zat gizi utama yang dikonsumsi oleh vegetarian karena makanan yang dijadikan lauk berasal dari tepung tepungan yang kemudian diolah menjadi gluten yang mirip dengan lauk hewani daging dan ikan. ${ }^{15,16}$ Bila dibandingkan dengan AKG 2013 untuk laki-laki berdasarkan kelompok umur 30-49 tahun sebesar 394 g/orang/hari, kelompok umur 50-64 tahun sebesar 349 g/orang/hari, sedangkan untuk perempuan kelompok umur 30-49 tahun sebesar 323 g/orang/hari, kelompok umur 50-64 tahun sebesar $285 \mathrm{~g} /$ orang/hari. Pada sampel vegan terdapat 11 orang $(26,2 \%)$ dengan asupan karbohidrat berlebih, dan hanya 6 orang $(14,3 \%)$ pada kelompok nonvegan dengan asupan karbohidrat yang berlebih.

Tabel 3 di atas menunjukkan, asupan karbohidrat vegetarian vegan sebesar 340,84 gram/orang/hari, sedangkan asupan karbohidrat nonvegan 305,16 gram/orang/hari. Menurut hasil uji statistik diperoleh nilai $<0,05$, maka $\mathrm{Ho}$ ditolak sehingga dapat disimpulkan bahwa ada perbedaan asupan karbohidrat pada komunitas vegetarian vegan dan nonvegan.

Protein merupakan zat gizi yang dibutuhkan untuk pertumbuhan, pembentukan serta pemeliharaan sel-sel dalam jaringan tubuh. Protein yang dikonsumsi akan disimpan di hati menjadi asam amino. Konsumsi protein yang berlebih akan disimpan dalam bentuk lemak. Namun, protein juga dibutuhkan sebagai pemasok energi bila kebutuhan dari zat gizi kurang mencukupi dan 1 gram protein menghasilkan 4 kkal. ${ }^{15}$ Bila dibandingkan dengan AKG 2013 yang didasarkan pada kelompok umur 30-49 tahun dan 50-64 tahun untuk laki-laki adalah sebesar 65 gram/orang/hari, sedangkan kelompok umur 30 49 tahun dan 50-64 tahun untuk perempuan adalah sebesar 57 gram/orang/hari. Didapati asupan protein berlebih sebanyak 8 orang $(19,0 \%)$, baik untuk kelompok vegan maupun nonvegan.

Tabel 3 di atas menunjukkan, asupan protein vegetarian vegan sebesar 62,54 gram/orang/hari, sedangkan asupan protein nonvegan 59,73 gram/orang/hari. Menurut hasil uji statistik nilai $p>0,05$, maka Ho diterima sehingga dapat disimpulkan bahwa tidak ada perbedaan asupan protein pada komunitas vegetarian vegan dan nonvegan.

Lemak merupakan zat gizi sumber energi paling besar, satu gram lemak mengandung 9 Kkal. Lemak didapati pada pangan hewani dan juga nabati. Pada komunitas vegetarian terutama vegan hanya mengonsumsi lemak dari nabati sepeti minyak kelapa sawit, minyak zaitun dan santan. ${ }^{16,17}$ Bila dibandingkan dengan AKG 2013 untuk lakilaki berdasarkan kelompok umur 30-49 tahun sebesar 73 gram/orang/hari, kelompok umur 50 64 tahun sebesar 65 gram/orang/hari, sedangkan untuk perempuan kelompok umur 30-49 tahun sebesar 60 gram/orang/hari, kelompok umur 50-64 tahun sebesar 53 gram/orang/hari. Pada sampel vegan terdapat 7 orang $(16,7 \%)$ didapati asupan lemak yang berlebih, sedangkan pada sampel nonvegan terdapat 13 orang $(30,9 \%)$ didapati asupan lemak yang berlebih.

Tabel 3 di atas menunjukkan asupan lemak vegetarian vegan sebesar 56,90 gram/orang/hari, sedangkan asupan lemak nonvegan 66,78 gram/orang/hari. Menurut hasil uji statistik diperoleh nilai $\mathrm{p}<0,05$, maka $\mathrm{Ho}$ ditolak sehingga dapat disimpulkan bahwa ada perbedaan asupan lemak pada komunitas vegetarian vegan dan nonvegan. Asupan zat gizi komunitas vegetarian distribusi klasifikasinya, dapat dilihat pada Tabel 4.

Tabel 4

Distribusi Asupan Zat Gizi pada Komunitas Vegetarian Vegan dan Non-Vegan

\begin{tabular}{|c|c|c|c|c|c|c|c|c|c|c|c|c|c|c|c|c|}
\hline \multirow{3}{*}{ Zat Gizi } & \multicolumn{8}{|c|}{ Vegan } & \multicolumn{8}{|c|}{ Non-Vegan } \\
\hline & \multicolumn{2}{|c|}{ Lebih } & \multicolumn{2}{|c|}{ Normal } & \multicolumn{2}{|c|}{ Kurang } & \multicolumn{2}{|c|}{ Jumlah } & \multicolumn{2}{|c|}{ Lebih } & \multicolumn{2}{|c|}{ Normal } & \multicolumn{2}{|c|}{ Kurang } & \multicolumn{2}{|c|}{ Jumlah } \\
\hline & $\mathrm{n}$ & $\%$ & $\mathrm{n}$ & $\%$ & $\mathrm{n}$ & $\%$ & $\mathrm{n}$ & $\%$ & $\mathrm{n}$ & $\%$ & $\mathrm{n}$ & $\%$ & $\mathrm{n}$ & $\%$ & $\mathrm{n}$ & $\%$ \\
\hline Energi & 19 & 22,6 & 19 & 22,6 & 4 & 4,7 & 42 & 100 & 19 & 22,6 & 23 & 27,3 & 0 & 0 & 42 & 100 \\
\hline $\mathrm{KH}$ & 23 & 27,4 & 19 & 22,6 & 0 & 0 & 42 & 100 & 13 & 15,5 & 21 & 25 & 8 & 9,5 & 42 & 100 \\
\hline Lemak & 14 & 16,7 & 13 & 15,5 & 15 & 17,8 & 42 & 100 & 26 & 30,9 & 8 & 9,5 & 8 & 9,5 & 42 & 100 \\
\hline Protein & 16 & 38,1 & 18 & 42,8 & 8 & 19 & 42 & 100 & 16 & 38,1 & 21 & 50 & 5 & 11,9 & 42 & 100 \\
\hline
\end{tabular}




\section{BAHASAN}

\section{Karakteristik Partisipan Penelitian}

Jenis kelamin dan umur merupakan salah satu faktor yang memberikan pengaruh besar terhadap penyakit sindroma metabolik dan degeneratif. Dari hasil penelitian ini menunjukkan wanita memiliki lingkar pinggang yang lebih lebar dibandingkan dengan laki-laki. Hal ini diperkuat oleh beberapa penelitian yang menyatakan bahwa wanita cenderung memiliki komposisi lemak tubuh yang lebih banyak dibandingkan dengan laki-laki pada kelompok usia yang sama. ${ }^{10,14}$

Prevalensi kejadian sindroma metabolik dan penyakit kronis (obesitas, hipertensi, dislipidemia), meningkat seiring bertambahnya umur. Risiko sindroma metabolik meningkat setelah umur 40 tahun. Pada penelitian ini sampel berusia 30-58 tahun berjenis kelamin laki-laki dan perempuan. Sampel terbanyak berumur 30-39 tahun dan 50-58 tahun. Proses perubahan terjadinya sindroma metabolik, diantaranya dapat dinilai dari lingkar pinggang dan IMT seseorang. Juga ditandai dengan penurunan kemampuan organ-organ tubuh baik dalam proses metabolisme maupun menjalankan fungsinya akan terjadi penurunan. ${ }^{5}$ 17

Jenis vegetarian vegan sebesar 50 persen dan nonvegan yang tersebar pada berbagai jenis vegetarian yaitu lakto ovo sebesar 37 persen, vegetarian lacto sebesar 8 persen dan vegetarian ovo sebesar 5 persen. Alasan komunitas vegetarian menjadi vegetarian vegan (murni) pada penelitian ini disebabkan karena alasan taatnya mereka pada ajaran agama yang dianutnya bahkan sejak kanak-kanak mereka sudah diajarkan untuk berpantang mengonsumsi makanan sumber hewani. Walaupun dilakukan secara bertahap, misalnya melakukan "free meat Monday". Alasan lainnya mereka dapat merasa lebih tenang serta merasa lebih sehat. Sementara pada kelompok jenis vegetarian lainnya, asumsi mereka hanya berpantang pada daging dan jenis ikan sehingga masih ada penganut vegetarian yang mengonsumsi telur dan susu sebagai makanan yang bersumber dari hewani, juga untuk menghindari kebosanan dan menghindari kekhawatiran terhadap anemia, karena kedua sumber makanan hewani ini mengandung vitamin B12 sebagai zat pembentuk Hb 1116
Analisis perbedaan lingkar pinggang ditinjau dari asupan energi, karbohidrat, protein dan lemak pada komunitas vegetarian vegan dan nonvegan

Dari hasil uji statistik uji beda $T$ Independent diperoleh hasil ini menunjukkan bahwa ada perbedaan lingkar pinggang. Perbedaan lingkar pinggang lebih besar pada kelompok nonvegan karena kelompok ini masih mengonsumsi sumber lemak jenuh yang berasal dari hewan dan nabati. Asupan lemak yang tinggi, akan diserap dalam bentuk kilomikron untuk dibawa ke hepar kemudian akan diubah menjadi berbagai fraksi lemak didalam darah untuk digunakan sesuai dengan fungsinya. Bila berlebihan akan terakumulasi dijaringan adiposa terutama dirongga perut yang disebut dengan obesitas visceral. Pada akhirnya akan mempengaruhi lingkar pinggang seseorang, terutama terjadi pada kelompok vegetarian yang berusia > 40 tahun dan dengan aktivitas rendah. Dari hasil penelitian ini untuk kelompok nonvegan didapatkan 61,1 persen mengalami obesitas sentral 1819

Sementara pada kelompok vegan dengan lingkar pinggang lebih kecil dapat dipengaruhi oleh konsumsi karbohidrat kompleks yang tinggi serat, di mana serat larut air dan tidak larut air yang terkandung dalam biji-bijian dan kacangkacangan dapat mengikat kelebihan lemak dan glukosa. Selain itu kelompok komunitas vegan sering mengonsumsi kacang kedelai dalam bentuk susu kedelai yang mempunyai zat bioaktif Isoflavon yang dapat bertindak menekan radikal bebas yang diakibatkan karena mengonsumsi lemak jenuh. ${ }^{20}$ Serat dan asam lemak tidak jenuh yang dikonsumsi vegetarian vegan diketahui mempunyai efek protektif terhadap sindroma metabolik terutama lingkar pinggang (obesitas sentral) ${ }^{12}$

Hal ini sejalan dengan penelitian yang dilakukan oleh Setiyani tahun 2012 yang menyatakan bahwa lingkar pinggang komunitas vegetarian vegan lebih rendah dibandingkan dengan nonvegan. Hal ini dikarenakan asupan vegetarian vegan tinggi asam lemak tidak jenuh dan serat yang diketahui mempunyai efek protektif terhadap sindroma metabolik, terutama lingkar pinggang. Pola makan vegan mengonsumsi banyak sumber zat-zat aktif seperti isoflavon, karbohidrat kompleks (serat) serta mengandung tinggi zat antioksidan (Vitamin C, E, serta Zn) yang banyak terdapat 
pada kacang-kacangan dan biji-bijian. Zat gizi ini dapat menetralisir dengan cara mengikat kelebihan lemak serta glukosa, di mana akumulasi lemak dan glukosa yang berlebih merupakan proses terjadinya lipogenesis di bagian perut (visceral), terutama orang-orang yang aktivitasnya juga rendah serta golongan mendekati lanjut usia.4,21 Jaringan lemak visceral (obesitas sentral) memiliki aktivitas yang tinggi baik pada lipogenesis maupun lipolisis, di mana akumulasi ini menginduksi kandungan asam lemak bebas, kelebihan asam lemak bebas dapat menyebabkan tingkatan sintesis lemak. Penelitian di Amerika menunjukkan diet vegan memiliki lingkar pinggang serta risiko sindrom metabolik yang lebih rendah dibandingkan dengan komunitas nonvegan. 9,22

Dalam penelitian ini juga mengungkapkan bahwa komunitas vegan lebih banyak mengonsumsi makanan yang mempunyai kandungan serat tinggi serta zat bioaktif yang di dapati terutama dari biji-bijian, di mana mampu meningkatkan kerja insulin dengan menurunkan absorbsi lemak dan peningkatan oksidasi lemak sehingga menurunkan akumulasi trigliserida melalui penghambatan adipogenesis, yang juga dapat mempengaruhi kerja gen sintesis asam lemak yaitu: Sterol Regulatory Element Binding Protein (SREBP) ${ }^{23}$

\section{Analisis perbedaan IMT ditinjau dari energi, karbohidrat, protein, dan lemak pada komunitas vegetarian vegan dan nonvegan}

Dari hasil uji statistik uji beda Tindependent diperoleh hasil yang menunjukkan tidak ada perbedaan IMT. Hal ini dikarenakan $\mathrm{KH}$ yang dikonsumsi vegan cenderung lebih banyak mengonsumsi biji-bijian dan kacangkacangan yang kaya akan serat. Salah satu diantaranya adalah biji flaxseed yang berasal dari bunga flax, biasanya dicampurkan atau ditaburkan didalam berbagai masakan. Flaxseed mengandung zat lignan yang berfungsi sebagai zat bioaktif yang dapat mengikat kelebihan glukosa dan tidak terjadi penimbunan glikogen di dalam otot sehingga secara otomatis akan menghambat pembentukan lemak konversi dari $\mathrm{KH}$. Pertambahan massa otot tidak yang tidak terjadi manifestasinya dapat dilihat dari nilai IMT penganut vegan dan nonvegan yang tidak berbeda. IMT dapat menggambarkan distribusi lemak tubuh yang sifatnya menyeluruh 24

Penelitian ini sejalan dengan penelitian Sutiari tahun 2008 yang menunjukkan bahwa status gizi normal berdasarkan IMTpada komunitas vegan dan nonvegan tidak berbeda nyata, hal ini kemungkinan disebabkan oleh aktivitas fisik pada nonvegan lebih tinggi dibandingkan dengan kelompok vegan. Sementara penelitian Pamungkas tahun 2012 juga menunjukkan ada perbedaan antara vegan dan nonvegan. IMT tidak hanya karena factor asupan energi, karbohidrat serta lemak yang berlebih juga dapat disebabkan karena aktivitas yang kurang, usia yang semakin bertambah serta yang di pengaruhi oleh faktor genetik. Dari 19 orang sampel vegan dan nonvegan didapati sebanyak 36 persen yang mempunyai berat badan lebih pada vegan, sedangkan pada nonvegan didapati 63 persen yang mempunyai berat badan lebih. IMT dengan kategori overweight dan obesitas merupakan prediktor terjadinya sindroma metabolik yang memiliki faktor risiko PJK dan DM yang cukup tinggi. ${ }^{5}$

Pada penelitian ini berdasarkan persentasi jumlah dengan kategori kelebihan berat badan dijumpai pada komunitas nonvegan, tetapi hasil uji statistik tidak menunjukkan perbedaan. Lamanya faktor menjadi seorang vegan kemungkinan menjadi pemicu terjadinya kegemukan serta usia juga faktor pendukung terjadinya berat badan yang berlebih. Seharusnya dengan pola makan komunitas vegan yang tinggi serat serta rendah asupan lemak dapat mengurangi terjadinya pembentukan lemak dijaringan adiposa. Namun, IMT dengan kategori lebih pada komunitas vegan dijumpai pada kelompok yang baru menjalankan pola makan vegan sekitar setahun, serta berusia rata-rata $>45$ tahun. Anjuran menjadi seorang vegan disebabkan oleh karena keinginan mentaati kaidah ajaran agama yang dianutnya yaitu Buddha Maitreya, di mana penganutnya diharuskan menjadi vegetarian vegan. ${ }^{10,21}$

\section{Perbedaaan asupan energi pada komunitas vegetarian vegan dan nonvegan}

Hasil uji statistik dengan uji T Independent diperoleh nilai probabilitas (sigtailed $=0,166)<0,05$, maka $\mathrm{Ho}$ diterima dan $\mathrm{Ha}$ ditolak sehingga dapat disimpulkan bahwa alpha 5 persen, yaitu tidak ada perbedaan 
asupan energi pada komunitas vegetarian vegan dan nonvegan. Komunitas vegetarian vegetarian mengonsumsi sumber energinya yang berasal dari gluten yang terbuat dari tepung (karbohidrat) dalam bentuk makanan seperti cai shio babi tepung, rendang gluten, ikan rumput laut, usus babi gluten, ikan sambal tongkol gluten, serta mie pangsit maitreya ataupun jenis menu yang lain, tetapi tetap menggunakan tepung sebagai bahan pembuatnya. Menu-menu ini dikonsumsi sebagai pengganti daging imitasi 1216 .

Hal ini sejalan dengan penelitian yang dilakukan oleh Sutiari tahun 2008 yang menyatakan bahwa konsumsi energi pada kelompok nonvegan terlihat lebih tinggi dibandingkan dengan kelompok vegan, tetapi secara analisis statistik tidak ada perbedaan. Hal ini menunjukkan bahwa pemenuhan kebutuhan pada kedua kelompok relatif sama, di mana kontribusi tertinggi konsumsi energinya berasal dari nasi, tepung-tepungan dan hasil olahannya serta sumber lemak. Penelitian yang membahas konsumsi jangka panjang diet vegan yang rendah energi serta rendah protein dikaitkan dengan penurunan beberapa komponen sindroma metabolik seperti propil lipid dan tekanan darah 1722

\section{Perbedaaan asupan karbohidrat pada komunitas vegetarian vegan dan nonvegan}

Hasil uji statistik dengan uji T Independent diperoleh nilai probabilitas (sig-tailed $=0,001$ ) < 0,05, maka Ho ditolak dan Ha diterima sehingga dapat disimpulkan bahwa alpha 5 persen, yaitu ada perbedaan asupan karbohidrat pada komunitas vegetarian vegan dan nonvegan. Komunitas vegetarian vegan mengonsumsi dalam jumlah banyak makanan yang mengandung karbohidrat, baik sederhana maupun kompleks, seperti nasi, ubi, talas, jagung. Selain itu mereka juga mengonsumsi buah-buahan seperti mangga, apel, pisang, kiwi dan anggur serta buah-buahan jenis lainnya yang disajikan, baik dalam bentuk jus, sop buah, maupun dikonsumsi langsung dan pengganti lauk, juga berasal dari konversi tepung-tepungan yang dibuat mirip dengan aslinya yang dibuat dalam berbagai variasi masakan. ${ }^{16}$

Hal ini tidak sejalan dengan penelitian Pamungkas tahun 2012 dan Setianingsih 2013 yang menyatakan bahwa tidak ada perbedaan asupan karbohidrat pada komunitas vegan dan nonvegan. Bila ditinjau dari asupan karbohidrat vegetarian vegan mengonsumsi bahan makanan yang mengandung karbohidrat dalam bentuk sederhana seperti gula tebu, buah buahan yang manis dan madu. Karbohidrat dalam bentuk sederhana ini akan segera dipakai menjadi energi. Pada vegetarian vegan konsumsi lemak jenuh dan kolesterol tergolong rendah. Karbohidrat akan berperan sebagai pengganti lemak jenuh dan pada kelompok vegan sehingga asupannya akan lebih tinggi. ${ }^{15,23}$

\section{Perbedaaan asupan protein pada komunitas vegetarian vegan dan nonvegan}

Hasil uji statistik dengan uji T Independent diperoleh nilai probabilitas (sig-tailed $=0,578$ ) > 0,05 , maka Ho diterima dan Ha ditolak sehingga dapat disimpulkan bahwa alpha 5 persen, yaitu tidak ada perbedaan asupan protein pada komunitas vegetarian vegan dan nonvegan. Hal ini dikarenakan vegetarian vegan mengonsumsi protein nabati dalam jumlah banyak dan frekuensi yang sering, sedangkan komunitas nonvegan, selain mengonsumsi protein kacangkacangan dan biji-bijian serta sumber gluten dari tepung, kelompok ini juga masih mengonsumsi protein hewani seperti susu dan telur dan dalam periode waktu yang lama seperti seminggu sekali. Dan bila dilihat dari kandungan protein dalam 100 gram bahan makanan tidak berbeda secara nyata. Hal ini tidak sesuai dengan penelitian yang dilakukan oleh Sutiari tahun 2008 dan Pamungkas tahun 2012 yang menyatakan bahwa ada perbedaan asupan protein pada komunitas vegan dan nonvegan. 5,24 Konsumsi protein yang berbeda tersebut disebabkan karena konsumsi kelompok nonvegetarian lebih beragam, di mana nonvegan masih mengonsumsi sumber protein dari hewani berupa susu dan telur dua tiga kali seminggu dengan kuantitas yang dikonsumsi seberat $>50$ gram.

\section{Perbedaaan asupan lemak pada komunitas vegetarian vegan dan nonvegan}

Hasil uji statistik dengan uji $T$ Independent diperoleh nilai probabilitas (sig-tailed $=0,005$ ) < 0,05 , maka Ho ditolak dan Ha diterima sehingga dapat disimpulkan bahwa alpha 5 persen, yaitu ada perbedaan asupan lemak pada komunitas vegetarian vegan dan nonvegan. Hal ini 
dikarenakan komunitas vegan untuk memenuhi kebutuhan sumber lemak, mereka selalu memakai kelapa dan santan untuk memberi rasa gurih dan menghindari kebosanan pada beberapa masakan seperti rendang gluten, sop buah, es jagung, bubur kacang hijau, kalio kacang merah dan lain-lain, sedangkan kelompok nonvegan, selain mengonsumsi jenis makanan, seperti vegan di atas, masih juga mengonsumsi sumber lemak dari susu, mentega, telur serta sesekali masih mengonsumsi ikan dan daging (minimal 1 bulan sekali). ${ }^{16,25}$

Penelitian ini sejalan dengan penelitian yang dilakukan oleh Jalal tahun 2008 di kota Padang yang meneliti pola makan masyarakat minang yang sering menggunakan kelapa dan santan untuk berbagai masakannya, di mana pola makan ini mirip dengan pola makan vegetarian dalam mengolah makanan. Namun, pada penelitian Sutiari (2008) tidak sejalan dengan penelitian ini karena walaupun konsumsi lemak pada nonvegan lebih tinggi, yang bersumber dari produk pangan hewani yang umumnya mengandung lemak yang relative lebih tinggi, tetapi secara statistik tidak ditemukan adanya perbedaan nyata. ${ }^{19,} 26$

\section{SIMPULAN DAN SARAN}

\section{Simpulan}

Hasil penelitian menunjukkan adanya perbedaan lingkar pinggang $(0,008<0,05)$, asupan karbohidrat $(0,001<0,05)$ serta asupan lemak $(0,005<0,05)$. Namun, komponen variabel $\operatorname{IMT}(0,105<0,05)$, asupan energi $(0,166>0,05)$ dan asupan protein $(0,578>0,05)$ tidak ada perbedaan pada komunitas vegan dan nonvegan di Medan.

\section{Saran}

Perlu dilakukan penelitian lanjutan tentang pola makan vegetarian vegan terhadap kejadian sindrom metabolik serta karakteristik kearifan pangan berdasarkan budaya setempat.

\section{RUJUKAN}

1. Reaven GM. The metabolic syndrome: is this diagnosis necessary? Am J Clin Nutr. 2006; 83(6): 1237- 47.

2. Sutiari NK. Konsumsi, Status Gizi, dan Kesehatan Masyarakat Vegetarian dan
Non Vegetarian di Bali. Tesis. Bogor: Institut Pertanian Bogor, 2008; 57-58. Available from:

http://repository.ipb.ac.id/handle/12345678 9/10290. Diakses pada tanggal 5 Maret 2014 pukul 14.00 WIB

3. Rohman MS. Patogenesis dan terapi sindroma metabolik. J Kardiol Ind. 2007; 28(2): 160-8.

4. Wiardani NK, Kusumayanti GAD. Indeks massa tubuh, lingkar pinggang serta tekanan darah penderita dan bukan penderita diabetes mellitus. JIG 2010; 1(1): 18-27.

5. Setiyani DA, Wirawanni Y. Perbedaan sindrom metabolik pada wanita vegetarian tipe vegan dan non-vegan. J Nutr Coll. 2012; 1(1): 216-23.

6. American Dietetic Association. Position of the American Dietetic Association Vegetarian Diet. J Am Diet Assoc. 2009; 109: 1267-8.

7. Indonesia, Badan Penelitian dan Pengembangan Kesehatan (Balitbangkes) Kementerian Kesehatan. Pokok-pokok Hasil Riset Kesehatan Dasar (Riskesdas) Indonesia 2013. Jakarta: Balitbangkes, 2013.

8. Hassan NE, Shebini SME, Ahmed NH, Mostafa MS. Association between macronutrients intake, visceral obesity and blood pressure in a sample of obese Egyptian women. OA Maced J Med Sci. 2015; 3(1): 184-8.

9. Jalal $\mathrm{F}$, Liputo $\mathrm{NI}$, Susanti $\mathrm{N}$, Oenzil $\mathrm{F}$. Lingkar pinggang, kadar glukosa darah, trigliserida dan tekanan darah pada etnis Minang di Kabupaten Padang Pariaman, Sumatera Barat. Media Medika Indonesiana. 2008; 43(3): 129-37.

10. Jian $\mathrm{ZH}$, Chiang $\mathrm{YC}$, Lung $\mathrm{CC}, \mathrm{Ho} \mathrm{CC}$, Ko $\mathrm{PC}$, Nfor $\mathrm{ON}$, et al. Vegetarian diet and cholesterol and TAG levels by gender. Public Health Nutr. 2015; 18(4): 721-6.

11. Fraser GE. Vegetarian diets: what do we know of their effect on common chronic diseases. Am J Clin Nutr. 2009; 89(5): 1607S-12S.

12. Huang CJ, Fan YC, Liu JF, Tsai PS. Characteristics and nutrient intake of Taiwanese elderly vegetarians: evidence from a national survey. $\mathrm{Br} J$ Nutr. 2011; 106(3): 451-60. 
13. Supariasa I, Dewa N, Bachyar B, Ibnu F. Penilaian Status Gizi. Jakarta: EGC, 2008.

14. Rizzo NS, Sabaté J, Jaceldo-Siegl K, Fraser GE. Vegetarian dietary patterns are associated with a lower risk of metabolic syndrome: the Adventist Health Study 2. Diabetes Care. 2011; 34(5): 1225-7.

15. Almatsier S. Prinsip Dasar IImu Gizi. Jakarta: Gramedia Pustaka Utama, 2009.

16. Siahaan $G$, Nainggolan $E$, Lestrina $D$. Hubungan asupan zat gizi dengan trigliserida dan kadar glukosa darah pada vegetarian. Ind J Human Nutr. 2015; 2(1): 48-59.

17. Almatsier S, Soetardjo S, Soekatri M. Gizi Seimbang dalam Daur Kehidupan. Jakarta: Gramedia Pustaka Utama, 2011.

18. Sutadarma IWG, Purnawati S, Ruma IMW. Hubungan stres kerja, status gizi, dan sindrom metabolik pada karyawan laki-laki dewasa. Gizi Indon. 2011; 34(1): 7-13.

19. De Biase SG, Fernandes SF, Gianini RJ, Duarte JL. Vegetarian diet and cholesterol and triglycerides levels. Arq Bras Cardiol. 2007; 88(1): 35-9.

20. Handayani W, Rudijanto A, Indra MR. Susu kedelai menurunkan resistensi insulin pada rattus norvegicus model diabetes melitus tipe 2. Jurnal Kedokteran Brawijaya. 2009; 25(2): 60-6.
21. Yang SY, Zhang HJ, Sun SY, Wang LY, Yan B, Liu CQ, et al. Relationship of carotid intima-media thickness and duration of vegetarian diet in Chinese male vegetarians. Nutr Met. (Lond). 2011; 8(1): 63.

22. Bedford JL, Barr SI. Diets and selected lifestyle practices of self-defined adult vegetarians from a population-based sample suggest they are more 'health conscious'. Int J Behav Nutr and Phys Act. 2005; 2(1): 4.

23. Mawarti $H$, Ratnawati $R$, Lyrawati $D$. Epigallocatechin gallate menghambat resistensi insulin pada tikus dengan diet tinggi lemak. Jurnal Kedokteran Brawijaya. 2012; 27(1): 43-50.

24. Rosell M, Appleby P, Key T. Height, age at menarche, body weight and body mass index in life-long vegetarians. Public Health Nutr. 2005; 8(7): 870-5.

25. Listiyana $A D$, Mardiana, Prameswari GN. Obesitas sentral dan kadar kolesterol darah total. Kemas. 2013; 9(1): 37-43.

26. Sugianti $E$, Hardiansyah, Afriansyah $N$. Faktor risiko obesitas sentral pada orang dewasa di DKI Jakarta. Gizi Indon. 2009; 32(2): 105-16. 